ISSN: 2515-6918, Online ISSN: 2515-6926

DOI: https://doi.org/10.1332/251569204X15668904587133

Volume 22, Issue 1-2, pages $91-104$

(c) AESP 2004

Go to section...

\title{
Old and New Theories of Fiscal Federalism, Organizational Design Problems, and Tiebout
}

\author{
Giampaolo Garzarelli \\ Dipartimento di Teoria Economica e Metodi Quantitativi, Università di Roma 'La Sapienza', Rome - Italy \\ E-mail:ggarzarelli@tiscali.it; fax +39064453870; tel. +390649910627
}

\section{ABSTRACT \\ Go to section...}

This work intends to contribute to the Second Generation Theory (SGT) of fiscal federalism that studies fiscal federalism through contemporary economic and industrial organization theory. First, it establishes context by introducing the two classic motivations in support of federalism, namely, incentives and knowledge. Second, it succinctly discusses the incentive-based organizational approach of the SGT. Third, it shows that the Tiebout model already embeds an organizational approach, which instead rests on a knowledge motivation.

\section{Keywords}

Economic organization, incentives, knowledge, Second Generation Theory of fiscal federalism 
Giampaolo Garzarelli

Dipartimento di Teoria Economica e Metodi Quantitativi, Università di Roma 'La Sapienza', Rome Italy

\section{Old and New Theories of Fiscal Federalism, Organizational Design Problems, and Tiebout}

Abstract - This work intends to contribute to the Second Generation Theory (SCT) of fiscal federalism that studies fiscal federalism through contemporary economic and industrial organization theory. First, it establishes context by introducing the two classic motivations in support of federalism, namely, incentives and knowledge. Second, it succinctly discusses the incentive-based organizational approach of the SGT. Third, it shows that the Tiebout model already embeds an organizational approach, which instead rests on a knowledge motivation.

Keywords - Economic organization, incentives, knowledge, Second Generation Theory of fiscal federalism

$7 E L$ classification codes - D79, H10, H77

\section{1. - Introduction}

The starting point of fiscal federalism - or the economic analysis of decentralized public governance - is that there are some economic functions that a central government should not be concerned with. Granted this, the substantive issue is organizational: to precisely define which functions should be centralized and which should be left to local jurisdictions (e.g., should health care and education be centralized or local?). Since the definition of 
the local versus central function most often also coincides with the public financing question - e.g., if local government is responsible for garbage collection, then should it also extract the garbage collection tax ${ }^{{ }^{1}}-$ the public organizational issue has become the staple of the public economist rather than of the organizational economist.

Apparently, in fact, the research of the public economist and the organizational economist is unrelated. Though both make use of the tools and principles of economics, public economists specialize in understanding the theory and practice of government intervention in terms of spending and taxation, and organizational economists in understanding industry structure and policy as well as the firm.

Recently, boundaries have been crossed. Fiscal federalism is now beginning to be analyzed through the lens of contemporary industrial and economic organization theory ${ }^{2}$.

The organizational approach that is emerging in local public finance has been called by Qian - Weingast [1997] Second Generation Theory of fiscal federalism (SGT). The present paper is concerned with the emerging SGT. It shows that the organizational approach of the SGT is in fact not so novel and tries to argue for a more balanced approach. The sections that follow

- establish context by quickly introducing the two classic motivations in support of federalism;

- suggest that other theories of public economics already implied an organizational approach;

- show that another, though complementary, organizational design view of public sector decentralization is implicit in Tiebout [1956];

- and, overall, argue that the positive heuristic of the SGT should also include the organizational approach implicit in Tiebout.

\footnotetext{
${ }^{1}$ Frey $[2001]$ subtly shifts the foundation of this taxation question from the hierarchy of governments to the spatial scope of governments. He suggests that the first best solution to this problem is «functional, overlapping, and competing jurisdictions», namely, competing governments without territorial monopoly. A proposal that, parenthetically, can seemingly be traced back as far as Montesquieu [1748/1989]; compare also Ostrom [1971/1987, pp. 129-130] and Boschken [1982] on the Federalist [1787-1788/2001]. Frey is optimistic about his proposal if it is constitutionally established, although he obviously recognizes the nonnegligible difficulties of achieving it. Volckart [2002] shows the existence of such governance structure in European history, but is more skeptical than Frey about the possibility of achieving it today.

${ }^{2}$ See, inter alia, Weingast [1995], Crémer et al. [1996], Seabright [1996], Garzarelli - Limam [2003], Tommasi - Weinschelbaum [2003], Garzarelli [2004], Josselin - Marciano [2004], and Oates [2004].
} 


\section{2. - The two classic motivations in favor of federalism}

It is possible to identify two classic motivations, which are actually the two faces of the same coin, favoring federalism.

The first motivation is incentive-based. It asserts that decentralized public governance is able to limit better than its centralized alternative the concentration of power in the hands of the few or the one. The rationale is simple: federalism aids the separation of powers by dividing a state into smaller, federated states. Differently put, federalism is seen as enhancing accountability in public governance, thus limiting inefficient behavior of various sorts. This motivation for decentralization is found especially in such classics as Montesquieu [1748/1989], Blackstone [1765/1960], Hamilton Jay - Madison [1787-1788/2001], de Tocqueville [1835/1990, Ch. 8, p. 160], and Acton [1907/1967, p. 98]. (We may in many ways consider this motivation as the economic equivalent of the familiar political checks and balances one.)

The second motivation is knowledge-based. It asserts that, contrary to its centralized alternative, decentralized public governance performs a beneficial cognitive function because, thanks to local jurisdictions, it is possible for citizens to more easily communicate their needs to government ${ }^{3}$. This other classic motivation is found in Hamilton-Jay - Madison [1787-1788/2001, e.g., Papers Nos. 30-36, pp. 145-79; see especially p. 172] and in de Tocqueville's Democracy in America. For example: in «great centralized nations the legislator is obliged to give a character of uniformity to the laws, which does not always suit the diversity of customs and of districts; as he takes no cognizance of special cases, he can only proceed upon general principles; and the population are obliged to conform to the requirements of the laws, since legislation cannot adapt itself to the exigencies and the customs of the population, which is a great cause of trouble and misery. This disadvantage does

\footnotetext{
${ }^{3}$ In the same spirit, decentralization moreover generates new knowledge, especially about policy options, because it enables federated states to perform various sorts of social experiments autonomously. Such experiments lead to diffused benefits within the federation as a whole because the various states, including the central one, can learn from the failures and successes of others. This related knowledge motivation for decentralization finds perhaps its clearest statement in Bryce [1888/2004, p. 257] and, later, United States jurisprudence: New State Ice Co. v. liebmann, 285 US 282, 1932 (Justice Louis D. Brandeis, dissenting). See also the opinions of Justice (Oliver Wendell Holmes, Jr. in Abrams v. United States, 250 U.S. 616, 1919 and Truax v. Corrigan, 257 U.S. 312, 1921 who, dissenting, defended the experimental nature of the First and the Fourteenth US Constitutional Amendments respectively. Justice Brandeis agreed with Justice Holmes in these cases. Though the laboratory role of federalism is related to the knowledge approach discussed here, a detailed discussion of it lies outside the scope of the present paper; but for an attempt to discuss the laboratory role in terms of the SGT, see Garzarelli [2004].
} 
not exist in confederations; Congress regulates the principal measures of the national government, and all the details of the administration are reserved to the provincial legislatures» [DE TOCQUEVILLE, 1835/1990, Ch. 8, p. 163, emphasis added].

As the next section shall elaborate, the more familiar theory of fiscal federalism - henceforth referred to as First Generation Theory or FGT though primarily taking its basic inspiration from both de Tocqueville and the Federalist [e.g., OATES, 1972, 1999], has primarily picked up the thread of the knowledge motivation. While the SGT has so far only focused on the incentive one. But, contrary to the FGT, the SGT is, as mentioned, a stillemerging research program. As such, its boundaries are not yet fully defined. It can therefore still easily accommodate the knowledge motivation for decentralization. Indeed, I will later suggest that Tiebout's work can be regarded not only as one of the seminal works of the FGT, but also, if indirectly, as a contribution containing the basics of a knowledge-based organizational approach that could complement the SGT.

\section{3. - First Generation, Second Generation, and other theories of fiscal federalism}

The FG' $T$, as just noted, favors federalism on knowledge grounds. By bringing the consumer-voter closer to the state, it suggests that decentralization helps to solve the value problem of the public sphere, that is, the problem of how to husband utility of a nonexcludable and nonrival good at efficient cost. The quintessence of such belief is arguably Oates's Decentralization Theorem, which proposes that «in the absence of cost-savings from the centralized provision of $»$ a local public «good and of interjurisdictional externalities, the level of welfare will always be at least as high (and typically higher) if Pareto-efficient levels of consumption are provided in each jurisdiction than if any single, uniform level of consumption is maintained across all jurisdictions» [OATES, 1972, p. 54, original emphasis].

The justification of such normative proposition - by Oates's [1999, pp. 1122-1124] own admission - is disarmingly simple. As de Tocqueville and Hamilton, Jay, and Madison implied, there's a higher probability of matching local public good demand if public good supply is not centralized, i.e., uniform across jurisdictions. When the Theorem doesn't hold, the central government will internalize (through grants-in-aid) interjurisdictional externalities until the federation's marginal social benefits equal marginal cost.

Such FGT conception is a legacy of the Samuelson [1954, 1955], Musgrave [1959] and Arrow [e.g., 1969/1977] public finance tradition. Since this tradition determines the internal functioning of state organization residually, it favors a familiar market failure argument the presumption of which is 
that both central and local governments act in the public interest. The main stimulus for the birth of the SGT is such anonymous conception of the state innate in the FGT. Much like the theory of the firm before Coase [1937] that sees organization as mere production function, the SGT does not consider the state as an organization. Simply put, it does not envision the state as a structure with problems of, for example, low-powered incentives and opportunistic behavior.

Be that as it may, the concrete matter of contempt raised by the SGT is that an anonymous conception of the state blocks off several avenues of theoretical investigation that could offer valuable information about the different public accountability effects of alternative public governance structures. Or, seen from a different perspective, the SGT contends that an organizational approach to local public finance can cast a brighter light on the incentive-aligning effects of decentralization. The SGT hence proposes to study such familiar issues as the possible transaction-cost minimizing role of the state, the proper assignment of decision rights among levels of government, and the alignment of incentives in the vertical structure of the public sector through the lens of contemporary organization theory. Let us briefly consider three SGT contributions from the New Institutional (or transaction cost) economics, incomplete contract and principal-agent perspectives to render this point a little more concrete $^{4}$.

Weingast's [1995, p. 1] SGT contribution is motivated by the following «fundamental political dilemma»: a «government strong enough to protect property rights and enforce contracts is also strong enough to confiscate the wealth of its citizens». The weak accountability constraints embodied in many public governance structures make politicians suffer from commitment myopia. One public governance structure that seems to work at different times and places - i.e., that allows for limited political intervention through economic checks and balances - is, suggests Weingast, federalism. Weingast accordingly calls his suggested SGT approach to decentralized public organization market-preserving federalism. The upshot of market-preserving federalism is that competing jurisdictions create incentives for credible commitments and lower transaction costs.

Seabright [1996] uses the 'incomplete contract' (or 'new property right') approach to analyze fiscal federalism [see also CRÉMER et al. 1996]. The typical setting of the incomplete contract framework is, of course, the firm; indeed, the party who manages to minimize rent-seeking costs is usually the owner of the firm. But since incomplete contracts include political man-

\footnotetext{
${ }^{4}$ See Oates [2004] for a more extensive and detailed review of the relevant literature.
} 
dates, constitutions and treaties, another setting could be public governance structures. It is thus suggested that a central government can maximize collective welfare through the possession of the residual rights for policy alignment among local governments - that is, for the offsetting of externalities among federated states. But the central government need not always act in the best interest of citizens; whereas decentralization, it is pointed out, can increase political accountability. In light of this trade-off, Seabright's model suggests that political accountability can be an organizational motivation for decentralization in spite of lack of difference of taste among local jurisdictions.

Tommasi - Weinschelbaum [2003] use one of the models proposed by the so-called common agency theory to explore the decentralization versus centralization decision. Like in the incomplete contract SGT approach, they suggest that interjurisdictional preference heterogeneity is not a sufficient condition to justify fiscal federalism: incentives also matter. They point out that a federally organized state may be a more efficient governance structure than a centralized one also - if not above all - for citizens (principals) to control politicians (agents) ${ }^{5}$.

Before proceeding to Tiebout I would like to succinctly make reference to two other approaches present in the literature that share similar concerns. These approaches are the Public Choice (PC) and the derived Political Economics.

The general organizational emphasis on incentives borrowed from organization theory that is now explicitly advocated in the subdiscipline of fiscal federalism does not imply that the overarching public economics literature has entirely neglected the organizational dimension of the public sector. PC has in fact made organization writ large a substantial part of its research program. Indeed, already in one of his earliest contributions Buchanan was unambiguous about the organizational nature of the state: the state is one instance of division of labor that emerges in order to pursue some ends through collective action, i.e., it is nothing more than the summation of individual wills the public cost curve of which (abstractly) remains an average and not a marginal one [BUCHANAN, 1949, p. 498].

For our purposes, the more specific issue to underscore is that in PC federalism basically enters the picture as a way to limit the grip of the fisc ${ }^{6}$. De-

5 Take note that the definition of who is the principal and who the agent in organizational models of fiscal federalism is a relative one; some studies view the central government as the principal. Josselin - Marciano [2004] offer a historical analysis of competition over principalship by using US Constitutional history as a case study, showing that such competition can cause conflicts among states and also vary principalship through time.

${ }^{6}$ Auster - Silver [1979] uses some industrial organization theory in what is an essentially PC framework to analyze the functions (or the output) of the state (but still considers state organization as a 
centralized public finance defines the proper scope and objective of government by allowing for competition among various levels of government. It creates incentives by injecting some market characteristics into the public, especially political, sphere. The incentive function of federalism is double: to limit the discretion of central state action and to limit the extraction of consumer-voters' surplus by local jurisdictions ${ }^{7}$. In sum, PC is principally concerned with avoiding a Leviathan state, and sees decentralization as one way to achieve this.

Persson - Tabellini [1996] focus on incentive issues among countries or regions that have decided to partake in macroeconomic risk. They point out that, under asymmetric information, the sharing of risk leads to the familiar moral hazard problem: when the principal (e.g., the EU central government) is the one offering the insurance protection, there is a high probability that the agents (EU member states) will work below their potential (e.g., will not fully absorb local macroeconomic shocks). The question that emerges is then of organizational design: which incentive structure best balances out the risk-sharing-moral hazard trade-off? Drawing on the incomplete contract, principal agent, and voting literatures in their Political Economics approach Persson and Tabellini conclude that, in certain cases, it is possible that a federal fiscal constitution allowing for centralized insurance protection can curb the distortions generated by moral hazard.

\section{4. - Tiebout: $A$ rereading}

The previous section points out that, contrary to the FGT, the SGT and other germane economic theories not only put forth an organizational argument for decentralization, but that such argument primarily hinges on

production function). For the distilled essence of the differences between the traditional public finance and Public Choice approaches see Buchanan - Musgrave [1999], wherein pages 155-202 are also dedicated to federalism. The work of Vincent Ostrom [e.g., 1971/1987 and OSTROM et al. 1961] is in some ways forerunning as well.

${ }^{7}$ The theme is also present in the subsequent New Institutional (or transaction cost) economics literature [e.g., NORTH, 1981; WEINGAST, 1995] that, as we saw, the SGT more explicitly views as central to its ken. In fact, at least prima facie, the only dividing line on the matter between the New Institutional Economics and PC would seem be the origin of the state. Through conjectural history, PC sees a contractual origin of the state [BRknNAN - BuChanan, 1985]; the New Institutional Economics conversely leaves matters open. North writes: whether «the state originated as a predatory group attacking and exploiting a peasant village - a predatory origin of the state - or developed out of the communal needs for organization of the peasant village - a contract origin of the state - cannot be resolved» [NOR'TH, 1981, p. 64]. 
an incentive-based motivation. This section rereads Tiebout's seminal contribution. It attempts to show that, similarly to the FGT, Tiebout offers a knowledge-based motivation for decentralization. But, unlike the FGT, such motivation is adduced by Tiebout on organizational grounds ${ }^{8}$.

'Tiebout's «A Pure Theory of Local Expenditures» is a critique of the Samuelson public finance argument ${ }^{9}$. In the Samuelson argument, public good allocation is often not 'optimal'. Unlike a market setting where consumers and producers reveal their preferences for private goods through supply and demand interaction, there is no market-type solution to determine the level of expenditure of public goods. The typical outcome in a public setting is in fact free-riding. The nonexcludability and nonrivalry properties of a public good assure that the public good is consumed irrespective of complete preference revelation. A constituent 'consumervoter' tends to minimize preference revelation, a magnitude directly related to personal tax burden, for he understands that he will still enjoy the public good thanks to the taxes paid by others. This 'market failure' calls, in the Samuelson argument, for state intervention along Pigouvian lines.

But two major questions arise. First, how can the state 'force' the full disclosure of consumer-voter preferences? Second, assuming full disclosure, can these preferences be satisfied like in a private goods market? Answering these questions is equivalent, according to Tiebout, to finding the 'optimal' solution to the problem of taxation. And the answer to these questions, Tiebout further observes, rests on devising «social institutions» [Tikвour, 1956, p. 418] that lead to market-like organization in the public sector, viz., in organizing the public sector so that it allows consumer sovereignty in the form of spatial mobility among competing jurisdictions according to public good preference.

Tiebout hence presents a model of local government expenditure that tries to determine the optimal level of public goods through a mechanism of preference revelation of the consumer-voter. He criticizes the Samuelson assumption that expenditures for public goods are handled at the central government level by arguing that several government services are provided at the local level too. Accordingly, he presents a spatial mobility model wherein the consumer-voter selects his preferred supply of public good by selecting among competing local jurisdictions: the consumer-voter discretionally moves to that community that most satisfies his set of

\footnotetext{
${ }^{8}$ Seabright [1996, p. 63, note 3] agrees: «Tiebout's model is best seen as a pioneering contribution to the theory of mechanism design, rather than saying anything about the decentralization of power in government».

"And thus also of the subsequent Musgrave and Arrow one.
} 
preferences. The Tiebout model is in this manner able to represent the preferences of the population more adequately than national level models; and at the same time yield a solution for the level of expenditures for local public goods. Thus, it was later said that in the Tiebout model people vote with their feet.

As Tiebout himself often underscores in his article, he is presenting a model with extreme assumptions. But what he was after in his purely theoretical piece, we hinted, is actually an organizational design problem. To Tiebout the attempt to approximate a market of the public sector, as it were, is in fact nothing more than a heuristic expedient devised to illustrate an organizational design issue or, if you prefer, a knowledge problem ${ }^{10}$. It is an informational or public-good externality that impedes the optimal amount of public good provision. In different terms, the reason for the lack of equivalence between the sum of the marginal rates of substitution and marginal cost à la Samuelson may be organizational.

This is particularly clear if one thinks that the optimal amount of public good provision is a relative or comparative matter: it varies with jurisdiction, notwithstanding mobility. As Oates recently observes in reference to the Tiebout model,

«the gains from decentralization, although typically enhanced by $[\ldots]$ mobility, are by no means wholly dependent on them. [...] In fact, if there were absolutely nothing mobile - households, factors, or whatever - there would still exist, in general, gains from decentralization. The point bere is simply that even in the absence of mobility, the efficient level of output of a 'local' public good, as determined by the Samuelson condition that the sum of the marginal rates of substitution equals marginal cost, will typically vary from one jurisdiction to another. To take one example, the efficient level of air quality in Los Angeles is surely much different from that in, say, Chicago» [OATES, 1999, p. 1124, my emphasis].

This point is important, for it shifts the focus of attention from market failure considerations to comparative institutional analysis. This opens the door to the consideration of different institutional or organizational arrangements for the internalization not only of physical and spatial externalities, such as nuisance and pollution, but also of those concerning production and ex-

${ }^{10}$ Fischel [2001, pp. $35 \mathrm{ff}$.] reports a personal anecdote. He learned from a conversation with Musgrave in 1994 that Tiebout had been a graduate student in Musgrave's class on public finance at Michigan. And that in such class Tiebout had the original idea about his now well-known model. But Tiebout, continued Musgrave, had brought up the idea in a jokingly manner - to not be taken too seriously. So, Tiebout's sense of humor - reported by many to be wonderful - is the primary culprit behind a contribution that Tiebout himself thought should not be taken too literally, but as an instance of provocation. 
change, or, in a word, organization. Relatedly, the emphasis on such other externalities does not a priori rule out that some organizational arrangements emerge not only to obviate detrimental but also to generate beneficial externalities of the same (and other) type ${ }^{11}$. As Tiebout [1956, p. 423] puts it, policies «that promote residential mobility and increase the knowledge of the consumer-voter will improve the allocation of government expenditures in the same sense that mobility among jobs and knowledge relevant to the location of industry and labor improve the allocation of private resources».

This other reading of 'Tiebout hints to a knowledge motivation for federalism from the organizational viewpoint. Indeed, although Tiebout arguably leaves matters open as concerns possible advantages of local government in internalizing public-goods or information type externalities [CRÉMER et al., 1996, pp. 41-43], the role played by taxes in his model is nonetheless a knowledge one: taxes perform a communication function for local public goods similar to that of the price system for private goods. And it is the induced competition among alternative organizational forms that transmits such knowledge; that reduces the uncertainty tied to marginal public good pricing.

Tiebout can, therefore, be interpreted as implicitly endorsing an avant la lettre comparative institutional analysis of two alternative governance structures of the public sector on knowledge grounds. The implied alternative real-world structures for preference revelation that are compared are the voting mechanism and local public finance. And the balance, as known, tips in favor of local public finance. But the spirit of comparative institutional analysis is in Tiebout as well. $\ll$ A general reduction of costs along with a reduction in one or more of the services provided cannot be justified on economic grounds unless the social welfare function is known. For example, those who argue for a metropolitan police force cannot prove their case on purely economic grounds. [...] If one of the communities were to receive less police protection after integration than it received before, integration could be objected to as a violation of consumer's choice» [TIEBOUT, 1956, p. 423].

In the Tiebout model the parties involved in the bargaining or communication process are the consumer-voters and the state qua organization. And it is the state that by means of this process should respond effectively to the needs of the consumer-voter [TIEBOUT, 1956, p. 417]. In the «Tiebout model», specifies for example Oates, «local jurisdictions use benefit taxes that effectively communicate to households the cost of consuming different levels of

1 Compare, for instance, Coase [1960], Demsetz [1969], Dahlman [1979], Crémer et al. [1996], and I anglois - Foss [1999]. This point also emerged earlier in the specific context of the organization of local governments in Ostrom's work on water supply, see for instance his later work with Tiebout and Warren, which also offers a summary of such point: Ostrom et al. [1961, pp. 838ff.]. Developing this connection in detail here would lead us too far astray. 
local public goods; this results in an efficient pattern of consumption of these goods. But this is true not only for households. If local governments provide local inputs that increase the productivity of capital employed in their jurisdictions, then they should levy benefit taxes on capital in order to provide the set of signals needed for the efficient deployment of capital across localities [...]» [OATES, 1999, p. 1125, emphasis added].

Or, to put it all in different words, when preference heterogeneity is high, it makes economic sense, for the provision of public goods, to reduce the 'cognitive distance' between the consumer-voter and the polity. The minimization of cognitive distance between the consumer-voter and the polity through fiscal decentralization is the 'program' one wishes to solve when searching the solution space of the vertical organization of the public sector. Because it involves specific knowledge, the solution to this program is necessarily an organizational one: creating local jurisdictions for consumer-voter mobility.

Let me take care at this point not to be misunderstood. I am not maintaining that the Tiebout model is a break from 'conventional' theory. That is, there is no doubt that the implicit benchmark against which the rhetoric of the Tiebout model rests is that of perfect competition theory - a theory devoid of any institutional or organizational substance ${ }^{12}$. If we nevertheless separate the rhetorical chaff from the substantive wheat we perceive a viewpoint that suggests that comparative organizational or institutional considerations are of the essence for questions concerning the vertical structure of the public sector. ${ }^{13}$ In brief, the Tiebout model embeds - if obliquely - an organizational view of public sector decentralization that emphasizes the knowledge motivation that the SGT has yet to consider.

\section{5. - Conclusion}

This explorative work tries to contribute to the interpretation of the Second Generation Theory of fiscal federalism. It begins by introducing the two classic motivations in favor of federalism, namely, incentive-alignment and knowledge. Then, it discusses the organizational approach that the SGT and other public economics literatures offer, and finds that they mostly focus on

\footnotetext{
${ }^{12}$ On which see, for example, Vihanto [1992].

${ }^{13}$ In fact, what more precisely Tiebout intentionally leaves out from his local public finance contribution is the political facet of the supply side. He is most explicit about this in his later contribution on the matter: this «paper is concerned with fiscal federalism - fiscal decentralization - purely from the point of view of economic efficiency. Alternatively stated, the problem is defined such that - as nearly as possible - political federalism is neutral» [TIEBOUI, 1961, p. 79]. This indirectly reinforces my view that Tiebout adduces a knowledge motivation for federalism. Compare on this point Fischel [2001].
} 
the incentive, rather than knowledge, motivation for decentralization. Finally, it points out that the Tiebout model already embeds an organizational approach that rests on a knowledge motivation, allowing us to discuss some knowledge functions of fiscal federalism from an organizational viewpoint.

Though this paper ultimately proposes that a SGT should include both the incentive and knowledge motivations for fiscal decentralization, it has not provided a polished theory of such proposition. Rather, it presented a sort of intellectual progress report. In order to provide a theory of such proposition, future studies should: (1) include a detailed discussion of knowledgebased approaches to economic organization with which the SGT may ally itself with; and (2) attempt to develop an organizational model of fiscal federalism based on the knowledge motivation.

Acknowledgements - Special thanks to Yasmina Reem Limam, Wallace E. Oates, and the two referees. 'The usual disclaimer applies.

\section{REFERENCES}

Acron, J. E. E. D., First Baron Acton of Aldenham, 1967, The History of Freedom and Other Essays (FigGIS, J. N. - LAURENCE R. V., eds), Freeport, N.Y., Books for Libraries Press (originally published 1907).

Arrow, K. J., 1977, «The Organization of Economic Activity: Issues Pertinent to the Choice of Market Versus Non-market Allocation», in HavEMAn, R. H. - MARGrolis, J. (eds), Public Expenditure and Policy Analysis (second edition), Chicago, Rand McNally College Publishing Company, pp. 67-81 (a partial reprint of an article originally published in 1969).

Auster, R. D. - Silver, M., 1979, The State as a Firm: Economic Forces in Political Development, Boston, Martinus Nijhoff Publishing.

BlaCkSTONE, W. Sir, 1960, Commentaries on the Laws of England (adapted by Kerr, R. W. with a «Preface» by HaAr, Ch. M.), Boston, Beacon Press (originally published 1765).

Boschiken, H. L., 1982, «Organization Theory and Federalism: Interorganizational Networks and the Political Economy of the Federalist», Organization Studies, 3, pp. 355-73.

Brinnan, G. - Buchanan, J. M., 1985, The Reason of Rules: Constitutional Political Economy, New York, Cambridge University Press.

Bryce, J. Viscount, 2004, The American Commonwealth, Volume 1 (with an «Introduction» by McDoweLL, G. L.), Indianapolis, Online PDF Liberty Fund edition (originally published 1888).

Bucl ianan, J. M., 1949, «The Pure Theory of Government Finance: A Suggested Approach», Fournal of Political Economy, 57, pp. 496-505. 
Buchanan, J. M. - Musgrave, R. A., 1999, Public Finance and Public Choice: Two Contrasting Views of the State, Cambridge, Mass., MIT Press.

COASE, R. H., 1937, «The Nature of the Firm», Economica, 4, pp. 386-405.

COASE, R. H., 1960, «The Problem of Social Cost», Fournal of Law and Economics, 3, pp. 1-44.

Crémer, J. - Estache, A. - Seabright, P., 1996, «Decentralizing Public Services: What Can We Learn from the Theory of the Firm?», Revue d'economie politique, 106, pp. 37-60.

Dahlman, C. J., 1979, «The Problem of Externality», Fournal of Law and Economics, 22, pp. 141-162.

DemseTz, H., 1969, «Information and Efficiency: Another Viewpoint», Fournal of Law and Economics, 12, pp. 1-22.

FISCHEL, W. A., 2001, «Municipal Corporations, Homeowners and the Benefit View of the Property Tax», in OATEs, W. E. (ed.), Property Taxation and Local Government Finance: Essays in Honor of C. Lowell Harriss, Cambridge, Mass., Lincoln Institute of Land Policy, pp. 33-77.

FREY, B. S., 2001, «A Utopia? Government without Territorial Monopoly», Fournal of Institutional and Theoretical Economics, 157, pp. 162-175.

GARZARELLI, G., 2004, Cognition, Incentives, and Public Governance: Laboratory Federalism from the Organizational Viewpoint, unpublished Paper.

GarZarelli, G. - Liman, Y. R., 2003, «Knowledge, Coordination, and Fiscal Federalism: An Organizational Perspective», in FranCO, D. - ZANARDI, A. (eds), I sistemi di welfare tra decentramento regionale e integrazione europea, Milan, Franco Angeli, pp. 231-240.

Hamilton, A. - JAY, J. - MADison, J., 2001, The Federalist (edited with an «Introduction» by CAREY, G. W. - MCClellaN, J.), Indianapolis, Liberty Fund (originally published 1787-1788).

Josselin, J.-M. - MARCIANO A., 2004, «Federalism and Conflicts over Principalship. Some Insights into the American Constitutional History», Constitutional Political Economy, 15, pp. 281-304.

LANGLOIS, R. N. - Foss N. J., 1999, «Capabilities and Governance: The Rebirth of Production in the Theory of Economic Organization», Kyklos, 52, pp. 201-218.

Montesquieu, Ch. de Secondat, baron de, 1989, The Spirit of the Laws (translated and edited by CoHLER, A. M. - Miller, B. C. - STONE, H. S.), New York, Cambridge University Press (first published 1748).

MusgraVE, R. M, 1959, The Theory of Public Finance, New York, McGraw-Hill.

NoRTH, D. C., 1981, Structure and Change in Economic History, New York, W. W. Norton \& Company, Inc.

OATEs, W. E., 1972, Fiscal Federalism, New York, Harcourt Brace Jovanovich, Inc.

OATES, W. E., 1999, «An Essay on Fiscal Federalism», Fournal of Economic 
Literature, 37, pp.1120- 1149.

OATEs, W. E., 2004, Toward a Second-generation Theory of Fiscal Federalism, unpublished paper.

Ostrom, V. - Tiebout, Ch. M. - WARREN, R., 1961, «The Organization of Government in Metropolitan Areas: A Theoretical Inquiry», American Political Science Review, 5, pp. 831-842.

Ostrom, V., 1987, The Political Theory of a Compound Republic: Designing the American Experiment (second edition, revised and enlarged), Lincoln, The University of Nebraska Press (first edition 1971).

Persson, T, - Tabellini, G., 1996, «Federal Fiscal Constitutions: Risk Sharing and Moral Hazard», Econometrica, 64, pp. 623-646.

QIAN, Y. - WEINGAST, B. R., 1997, «Federalism as a Commitment to Preserving Market Incentives», Fournal of Economic Perspectives, 11, pp. 83-92.

SAmUELSON, P. A., 1954, «The Pure Theory of Public Expenditure», Review of Economics and Statistics, 36, pp. 387-389.

SAmUElson, P. A., 1955, «Diagrammatic Exposition of a Theory of Public Expenditure», Review of Economics and Statistics, 37, pp. 350-356.

SEABRIGHT, P., 1996, «Accountability and Decentralization in Government: An Incomplete Contract Model», European Economic Review, 40, pp. 61 89.

Tiebour, Ch. M., 1956, «A Pure Theory of Local Expenditures», Fournal of Political Economy, 64, pp. 416-424.

TIEBouT, Ch. M., 1961, «An Economic Theory of Fiscal Decentralization», in Universities - National Bureau CommitTeE for ECONOMIC ReSEARCH, Public Finances: Needs, Sources, and Utilization, Princeton, Princeton University Press, pp. 79-96.

Tocqueville, A. DE, 1990, Democracy in America, Volume I (with a «New Introduction» by Boorstin, D. J.), New York, Vintage Classics (first published 1835).

Tommasi, M. - Weinschelbaum, F., 2003, Centralization vs. Decentralization: A Principal-agent Analysis, working paper, Universidad de San Andrés, Argentina.

VIHANTO, M., 1992, «Competition between Local Governments as a Discovery Procedure», Fournal of Institutional and Theoretical Economics, 148, pp. 411-436.

VOLCKART, O., 2002, «No Utopia: Government without Territorial Monopoly in Medieval Central Europe», fournal of Institutional and Theoretical Economics, 158, pp. 325-343.

WeINGAST, B. R., 1995, «The Economic Role of Political Institutions: Market-Preserving Federalism and Economic Growth», Fournal of Law, Economics, and Organization, 11, pp. 1-31. 